\title{
Problem Sensitivitas Touch Screen Sebagai Alat Antar Muka Antara End-user dan Perangkat Elektronik
}

\author{
Saludin Muis ${ }^{1^{*}}$, Didik Setiyadi ${ }^{1}$ \\ ${ }^{1}$ Teknik Informatika, Universitas Bina Insani, Jl. Siliwangi No.6 Rawa Panjang Bekasi Bekasi \\ Timur 17114 Indonesia; Telp. (021) 82436 886, Fax. (021) 824009 24; \\ e-mail: didiksetiyadi@binainsani.ac.id \\ *Korespondensi: email: saludinmuis@hotmail.com
}

Diterima: 8 November 2020; Review: 12 November 2020; Disetujui: 19 November 2020, 53-62;

Cara sitasi: Muis S., Didik Setiyadi. 2020. Problem Sensitivitas Touch Screen Sebagai Alat Antar Muka Antara End-user dan Perangkat Elektronik. Informatics for Educators and Professionals. 5(1): 63-74.

Abstrak : Touch screen adalah perangkat yang menggantikan fungsi papan ketik dan mouse sebagai alat antar muka antara end user dengan perangkat elektronik, dimana berkomunikasi antara end user dan perangkat eletronika dilakukan. Karena itu faktor sensitivitas pendeteksian sentuhan jari atau obyek luar menjadi hal penting pada perangkat touch screen untuk pemakaian khusus. Hal ini berhubungan dengan kecepatan respon touch screen yang menentukan laju data yang diterima perangkat elektronika. Kurang sensitif jalur-jalur tertentu pada touch screen dikenal dengan istilah phase delay, yang efeknya adalah waktu respon touch screen menjadi lebih panjang, bahkan dalam kondisi parah, dapat terjadi kesalahan data. Penelitian ini mengambil kasus produk Apple yaitu Iphone dimana phase delay disebabkan oleh pergeseran nilai resistansi pada jalur bahan ITO yang terkorelasi dengan kontaminasi selama proses sputter lapisan nanometer ITO.

Kata kunci : touch screen, sensitivitas, phase delay, resistansi, ITO.

\begin{abstract}
Touch screen is a device that replaces keyboard and mouse functions as an interface tool between end users and electronic devices, where communication between end users and electronic devices is carried out. Because of that, the sensitivity factor of detecting the touch of a finger or an external object is important for touch screen devices for special use. This is related to the touch screen response speed which determines the rate of data received by electronic devices. Less sensitive certain paths on the touch screen are known as phase delays, the effect of which is that the touch screen response time is longer, even in severe conditions, data errors can occur. This research takes the case of Apple product, namely Iphone, where the phase delay is caused by a shift in the resistance value in the ITO material path which is correlated with contamination during the ITO nanometer sputter layer process.
\end{abstract}

Keywords : touch screen, sensitivity, phase delay, resistance, ITO.

\section{Pendahuluan}

Touch screen /layar sentuh jenis kapasitif yang dipakai produk Iphone produksi perusahaan Apple menggunakan struktur lapisan ITO yang disebut DITO (Double side ITO) $[1,2,3]$, dimana titik-titik koordinat dibentuk dari matriks jalur $x-y$ yang dipola dari bahan ITO (bahan logam dengan sifat transparan/tembus pandang, gambar 1) yang disputter $[4,5]$ pada kedua sisi permukaan lembaran gelas untuk membentuk sifat kapasitif pada koordinat matriks $x-y$. Satu sisi untuk jalur $x$ dan satu sisi lainnya untuk jalur y (gambar2). Adapun sinyal pelarikan/scaning (baik struktur DITO maupun SITO menggunakan prinsip yang sama) dari perangkat elektronik pengontrol menginjeksi deretan sinyal pulsa kotak (gambar 3) lewat jalur y 
(disebut driving) dan diterima lewat jalur $x$ (disebut jalur sensing) [8]. Lewat sinyal kontrol inilah perangkat elektroik pengontrol mendeteksi posisi pada permukaan touch screen yang tersentuh oleh obyek luar berupa jari maupun pena khusus.

\section{Perbedaan Nilai Resistif Pada Matriks x-y}

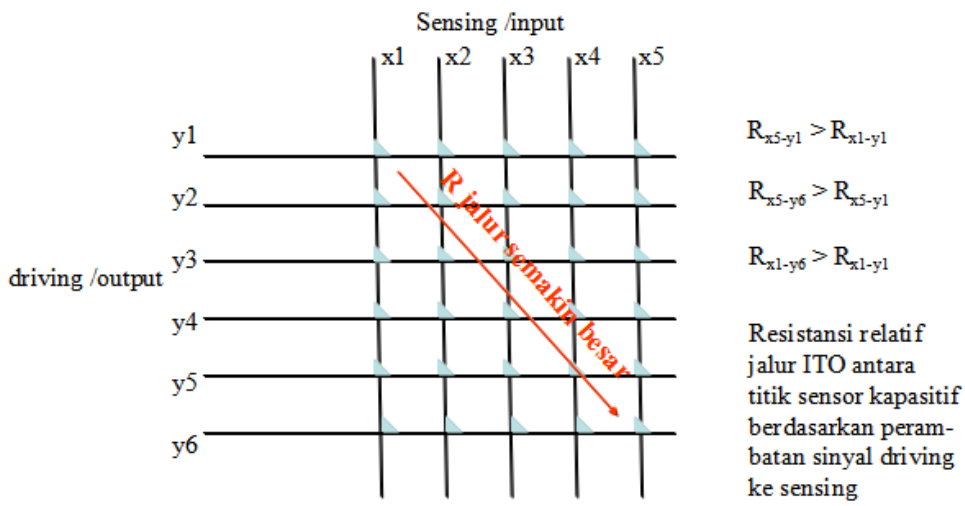

Sumber: Hasil Penelitian (2020)

Gambar 1. Matriks x-y Pembentuk Koordinasi Touch Screen

Struktur DITO pada produk touch screen Iphone

Conductive plate(pada sisi atas dan

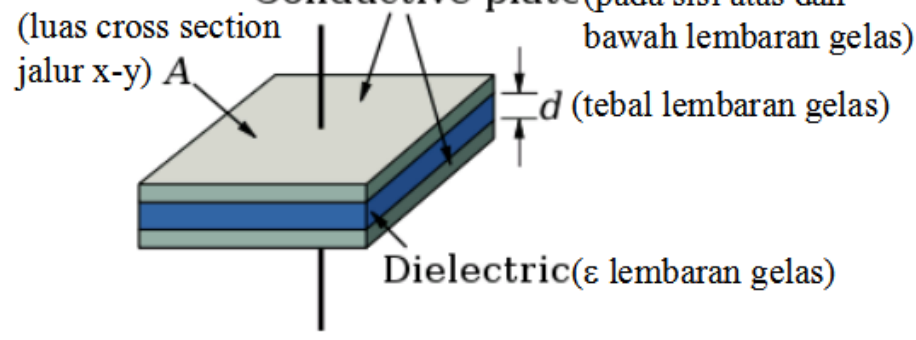

Catatan : nilai kapasitif : $C=\frac{\varepsilon A}{d}$.

Sumber: Hasil Penelitian (2020)

\section{Gambar 2. Struktur Touch Screen DITO}

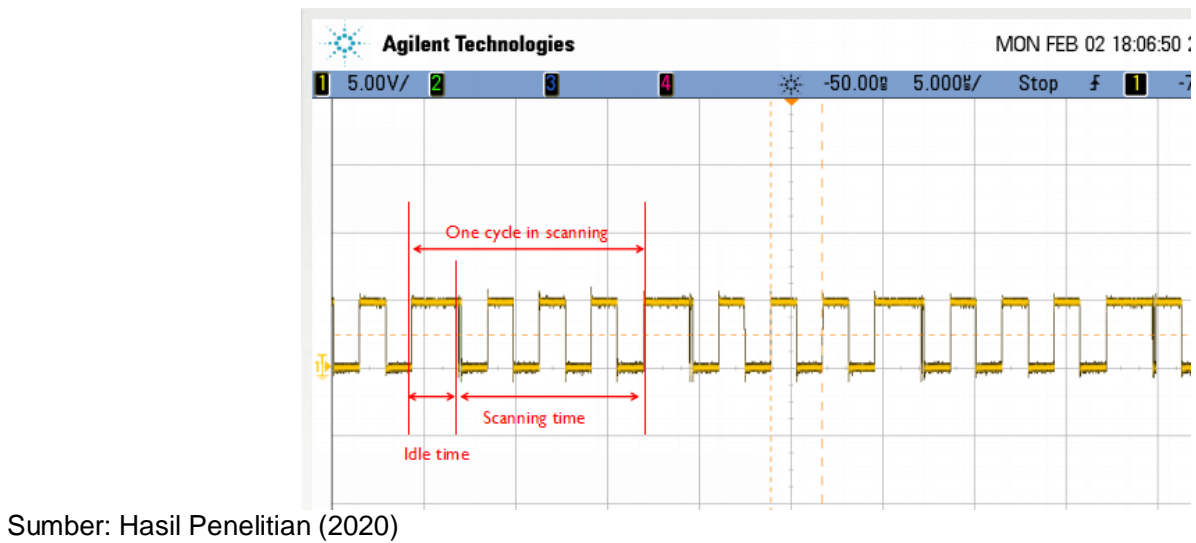

Gambar 3. Sinyal Kotak Untuk Pelarikan Matriks x-y

Cara kerja modul touch screen cukup sederhana, perangkat elektronik pengontrol akan menginjeksi sinyal pelarikan pada tiap jalur ITO driving (y), kemudian dideteksi lewat jalur ITO sensing $(\mathrm{x})$, jadi pada prinsipnya jalur $\mathrm{x}-\mathrm{y}$ berupa lingkar tertutup yang terkopel oleh sebuah 
"kapasitor" pada tiap titik perpotongan (tipe touch screen demikian disebut tipe kapasitif) $[9,10]$. Proses pendeteksian :

1). Selama waktu pelarikan (scaning time), semua kapasitor pada jalur driving terkait akan terisi (charge) muatan listrik. 2). Bila ada obyek luar baik berupa ujung jari ataupun pena khusus menyentuh permukaan touch screen, maka terjadi pembuangan (discharge) muatan listrik. 3). Lewat perbedaan antara titik-titik yang seharusnya terisi muatan (kondisi normal) dan titik dimana terjadi pengosongan muatan listrik (kondisi tersebut oleh obyek luar), maka perangkat elektronik pengontrol yang terprogram (dikontrol secara perangkat lunak), mampu mendeteksi posisi koordinat pada matriks $x-y$ yang tersentuh secara tepat.

Untuk poin ke 3 pada proses pendeteksian diatas, perlu memahami nilai kapasitor yang terbentuk oleh matriks $x-y$ dan nilai resistansi dari tiap jalur ITO yang dilalui arus listrik dimana hasil perkalian RC merupakan konstanta waktu $\tau$. Nilai kapasitor (gambar 2, persamaan 1) dan nilai resistansi (gambar 4, persamaan 2) sebagai berikut :

$\mathrm{C}=\mathrm{e} A / \mathrm{d}$ satuan Farad

$\sigma=1 / \rho=n|e| \mu$

$\sigma=$ konduktivitas, $\mathrm{n}=$ jumlah elektron bebas, $\mathrm{m}=$ mobilitas.

Mobilitas dipengaruhi oleh : (1) Impurity atoms, (2) Vacancies, (3) Interstitial atoms, (4) Dislocations, (5) Thermal vibrations of the atoms themselves. Sedangkan resistivity $\rho$ dipengaruhi oleh : (1) Temperature $->$ thermal vibration, (2) Composition $->$ impurities, (3) The degree of cold work of a metal specimen $->$ plastic deformation.

Jalur penghantar dengan resistivity $\rho$, , panjang $\mathrm{L}$ dan luas penampang $\mathrm{A}$

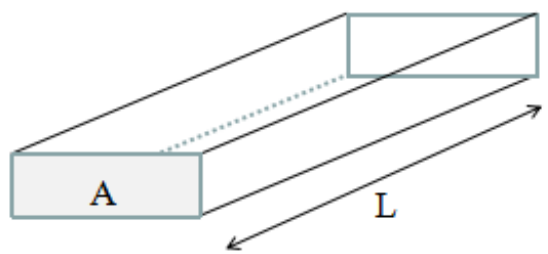

Catatan : nilai $\mathrm{R}=\rho \mathrm{L} / \mathrm{A}$

Sumber: Hasil Penelitian (2020)

Gambar 4. Nilai Resistansi Suatu Penghantar

Proses pengisian (persamaan 3) dan pembuangan muatan listrik (persamaan 4) oleh kapasitor dengan asumsi sinyal kotak ( $\left.\mathrm{V}_{0}\right)$ dianggap sebagai level dc (arus rata). rangkaian kapasitor dan resistansi pada jalur matriks $x$-y disederhanakan pada gambar 5 , sedangkan secara grafik untuk pengisian dan pembuangan muatan pada $C$ diilustrasikan pada gambar 6 .

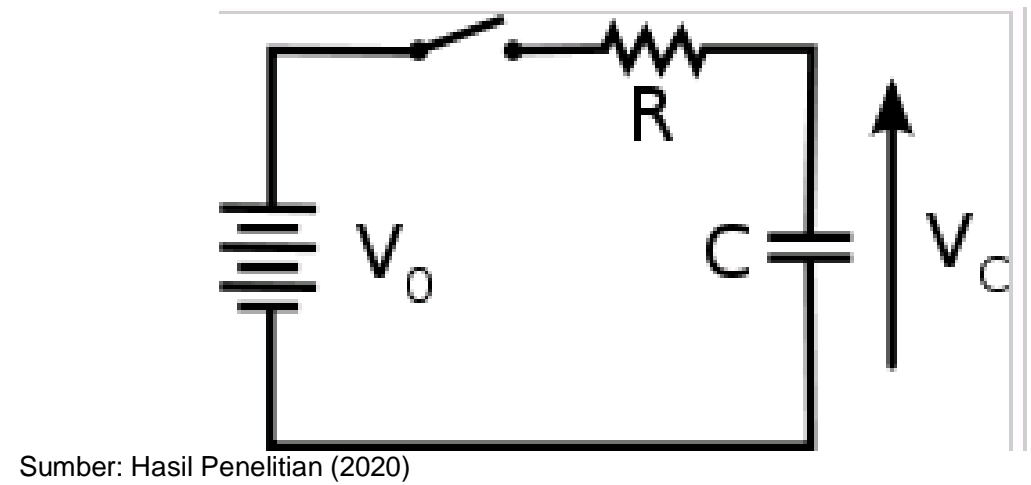

Gambar 5. rangkai $\mathrm{RC}$ pada matriks $x-y$ 


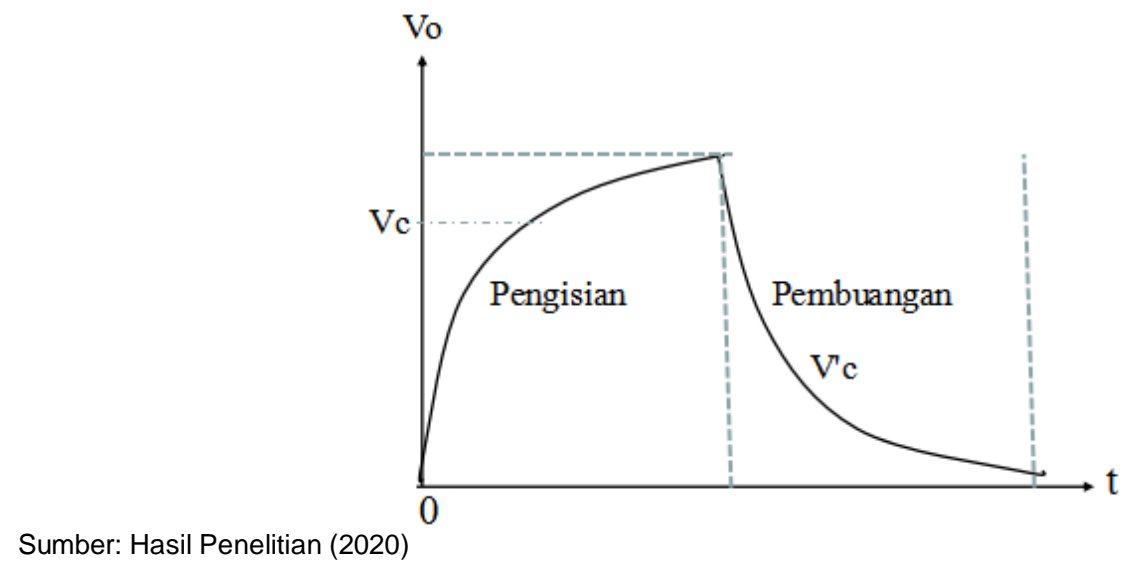

Gambar 6. Grafik tegangan listrik $V_{c}$ pada kapasitor

Selama waktu pengisian muatan :

$$
\begin{aligned}
& V_{c}=V_{o}\left(1-e^{-t / \tau}\right) \ldots \ldots \ldots \ldots \ldots \ldots \ldots \ldots \ldots \ldots \ldots \ldots \ldots \ldots \ldots \\
& \left(1-e^{-t / \tau}\right)=\left(t / \tau-(t / \tau)^{2} / 2 !+(t / \tau)^{3} / 3 !-(t / \tau)^{4} / 4 !+\right.
\end{aligned}
$$

Selama waktu pembuangan muatan :

$$
\mathrm{V}^{\prime} \mathrm{c}=\mathrm{V}_{\mathrm{c}} \mathrm{e}^{-\mathrm{t} / \tau}
$$

Disini perlu ditekankan bahwa pada kasus yang diteliti, pendeteksian titik-titik koordinat pada permukaan touch screen bekerja berdasarkan logika digital, yaitu "0" (ketika kapasitor membuang muatan listrik karena ada obyek luar yang menyentuh permukaan touch screen) atau "1" (ketika proses scanning, dimana semua kapaitor pada jalur driving terisi muatan listrik). Aras logika "0" dan "1" didefinisikan berdasarkan level tegangan listrik, misalkan untuk gerbang logika dengan tegangan kerja $5 \mathrm{~V}$ :

1. Aras logika "0" adalah untuk tegangan listrik dibawah $0.4 \mathrm{~V}$

2. Aras logika "1" adalah untuk tegangan listrik diatas $2.4 \mathrm{~V}$.

Berdasarkan persamaan (3) dan (4) dan level tegangan listrik untuk aras logika "0" dan "1", dan waktu scanning maupun pendeteksian / sensing yang mengacu kepada deretan pulsa kotak yang terprogram secara periodik melakukan pelarikan terhadap matriks $x-y$, maka bila konstanta waktu $\tau$ berubah signifikan, dapat menyebabkan aras logika "0" tidak terdeteksi dengan benar (problem phase delay). Dari aspek teori, hal demikian dapat diatasi lewat perangkat lunak (program) yang ditanamkan pada perangkat elektronik pengontrol, akan tetapi pelebaran waktu scanning atau pendeteksian, secara teknis mengurangi sensitivitas fungsi touch screen. Disamping itu trade off antara problem phase delay dan "batasan pelebaran waktu" yang ditoleransikan lewat rekayasa ulang perangkat lunak, pada dasar hanya menambah kompleksitas rancangan modul, bukan menyelesaikan problem phase delay sebagaimana semestinya.

\section{Metode Penelitian}

Penelitian ini termasuk dalam kategori penelitian kasus. Menggunakan cara mengukur parameter (peralatan ukur yang terkompurisasi) dan pengamatan visual ( menggunakan SEM) yang berhubungan dengan konstanta waktu $\tau$ (unsur $C$ dan $R$ ) yang terkorelasi dengan gejala kegagalan fungsi modul touch screen yang dinyatakan sebagai problem phase delay. Modul touch screen disini didefinisikan terdiri dari : (1). Sub-modul matriks $x-y$, dimana pada permukaan sisi terluar, obyek luar dapat penyentuhnya untuk mengaktifkan fungsi "sentuh" terhadap modul touch screen. (2). Sub-modul perangkat elektronik pengontrol, yang disambungkan ke sistem perangkat keras induk atau peralatan utama yang memanfaatkan modul touch screen sebagai alat antar muka ke end user.

Hipotesis penyebab problem phase delay ditekankan dan dibangun dari elemen $R$ karena secara struktur, elemen $\mathrm{C}$ adalah stabil. Dengan demikian penelitian diarahkan untuk mencari bukti visual adanya kerusakan secara fisik (akibat ketidaksempurnaan proses sputter dan/atau kontaminasi selama proses [6,7]) pada jalur ITO yang membentuk sensor berupa 
matriks $x-y$ dengan menggunakan mikroskop elektron. Adapun tahapan berikut pada gambar 7:

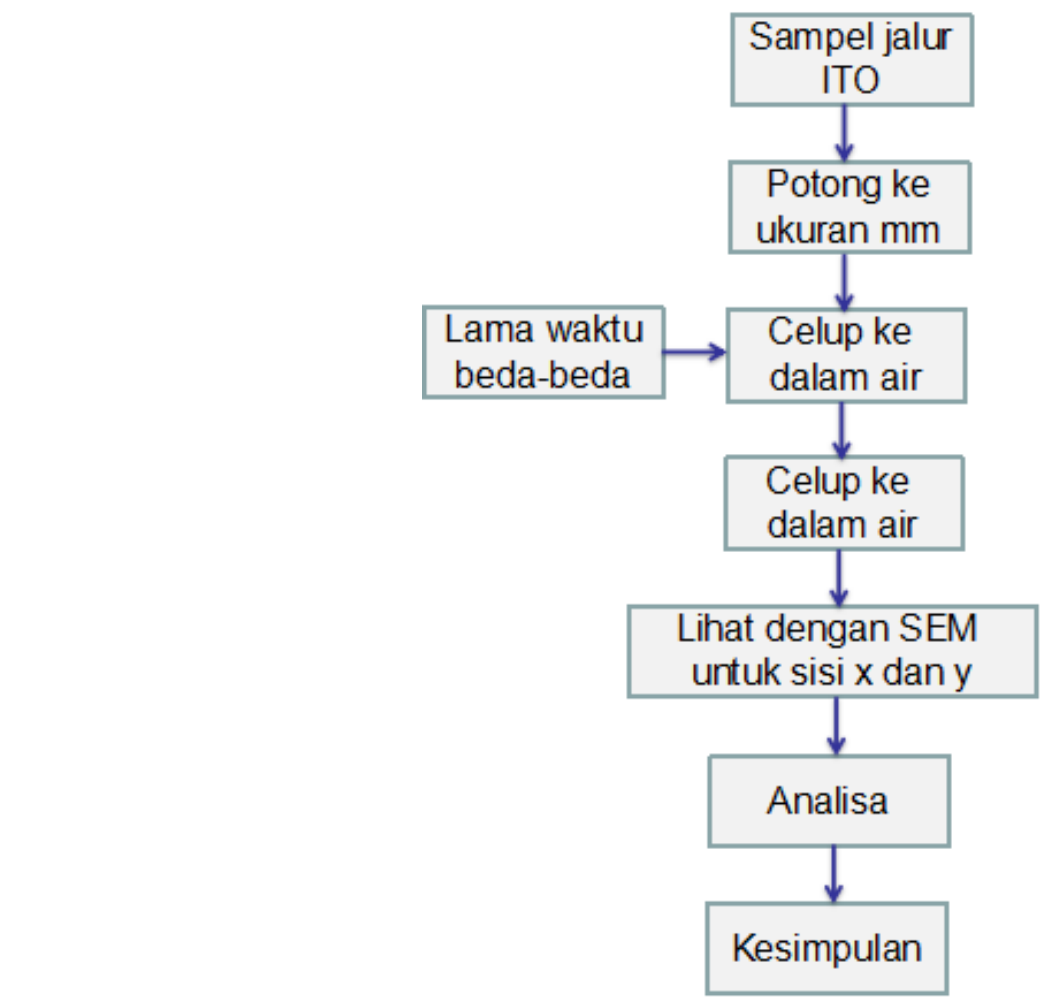

Sumber: Hasil Penelitian (2020)

Gambar 7. Tahapan penelitian perubahan nilai $R$ pada jalur matriks $x-y$ secara visual

Catatan : Sampel jalur ITO diekstrak dari modul touch screen yang memiliki problem phase delay pada produk Iphone yang diumpan-balikan oleh Apple, untuk dicarikan root cause atau penyebabnya.

\section{Hasil dan Pembahasan}

Hasil

Data berupa foto diambil dengan alat SEM untuk sisi jalur ITO atas dan bawah (sesuai struktur DITO) dengan perbedaan waktu celup ke dalam air bersih 20 menit (gambar 8), 30 menit (gambar 9), 50 menit (gambar 10), 60 menit (gambar 11) dan 80 menit (gambar 12), yang diamati dengan menggunakan mikroskop elektron. Foto-foto pada permukaan sampel dengan waktu celup beda dalam air bersih sebagai berikut (Catatan : pengukuran secara kuantitatif menggunakan peralatan elektronik terkomputerisasi pada lokasi matriks $x-y$ touch screen yang bermasalah dengan problem phase delay tidak diperlihatkan disini, dengan alasan terlalu bersifat teknis dan membutuhkan interpretasi serta penjelasan yang rumit) : 


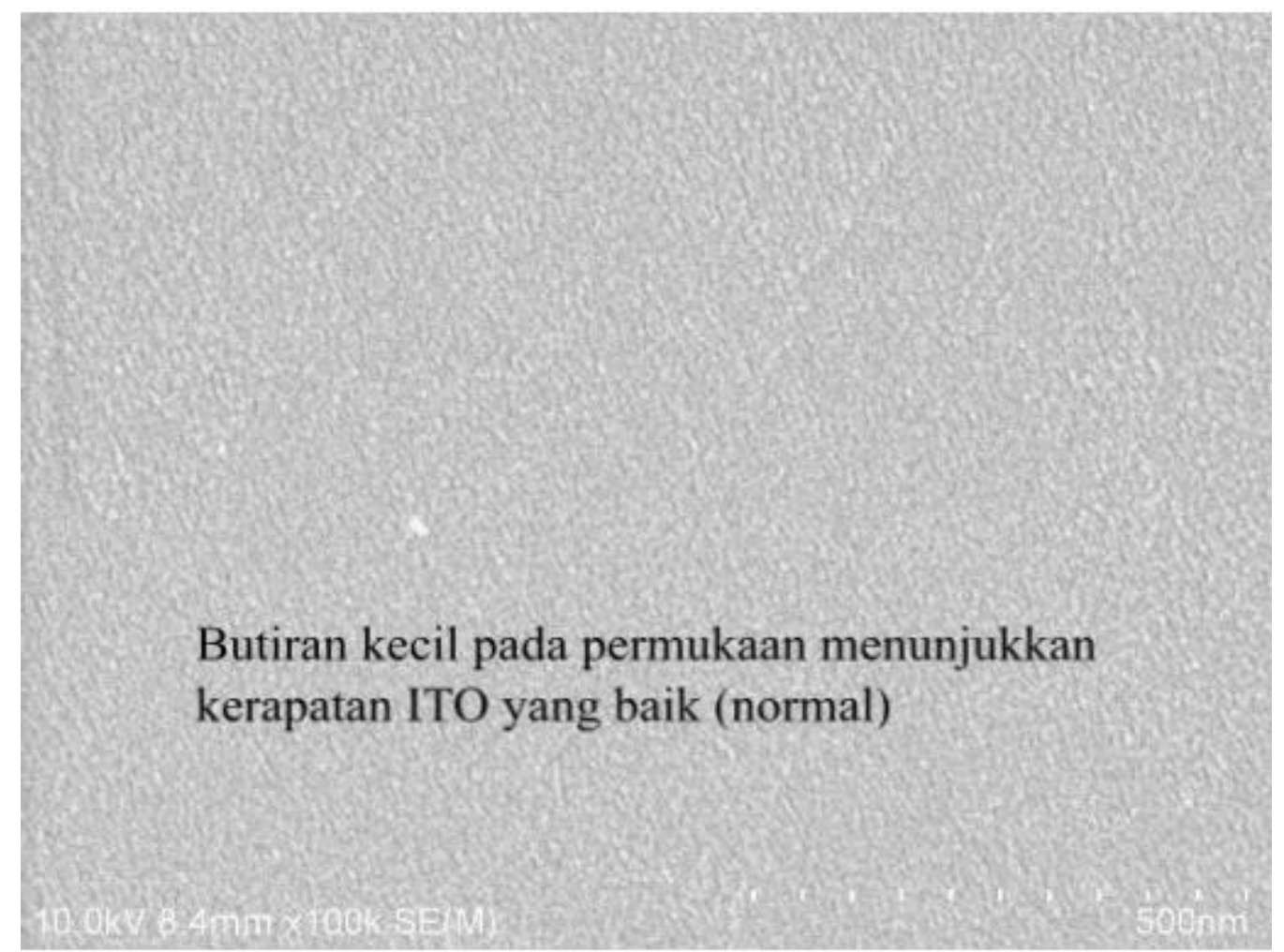

(a) Sisi Atas

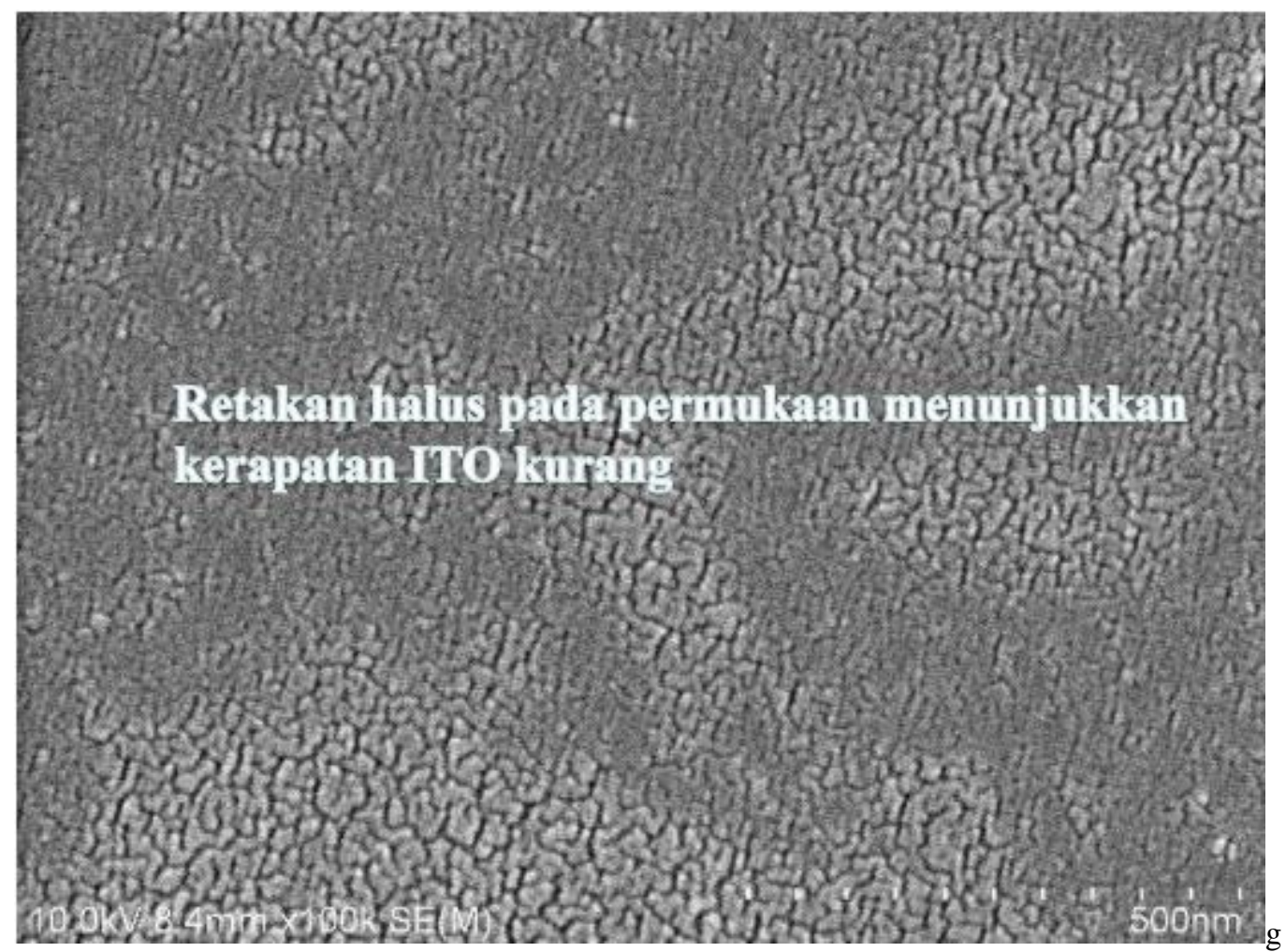

(b) Sisi bawah

Sumber: Hasil Penelitian (2020)

Gambar 8. Waktu celup dalam air 20 menit 


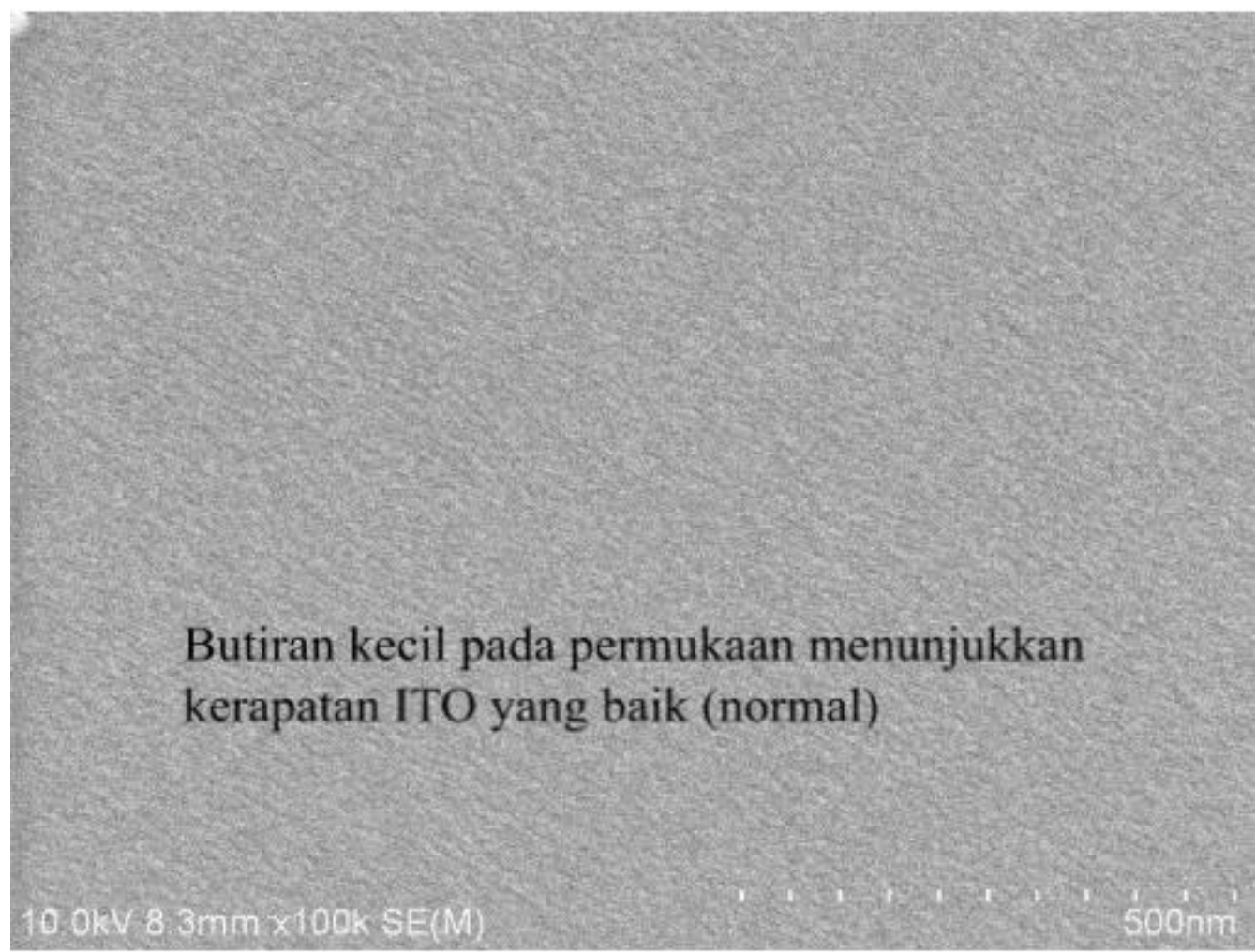

(a) Sisi Atas

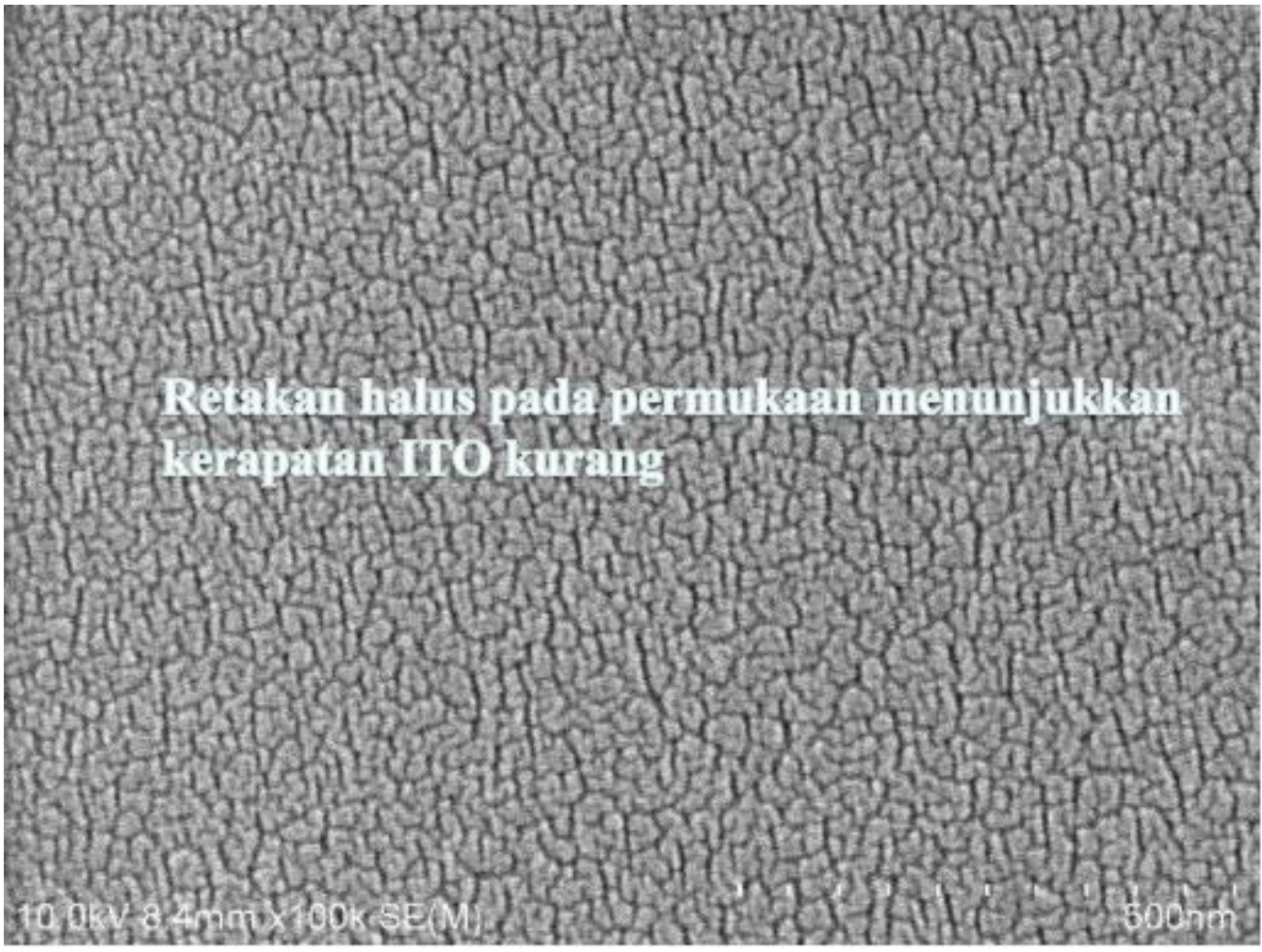

(b) Sisi bawah

Sumber: Hasil Penelitian (2020)

Gambar 9. Waktu celup dalam air 30 menit 


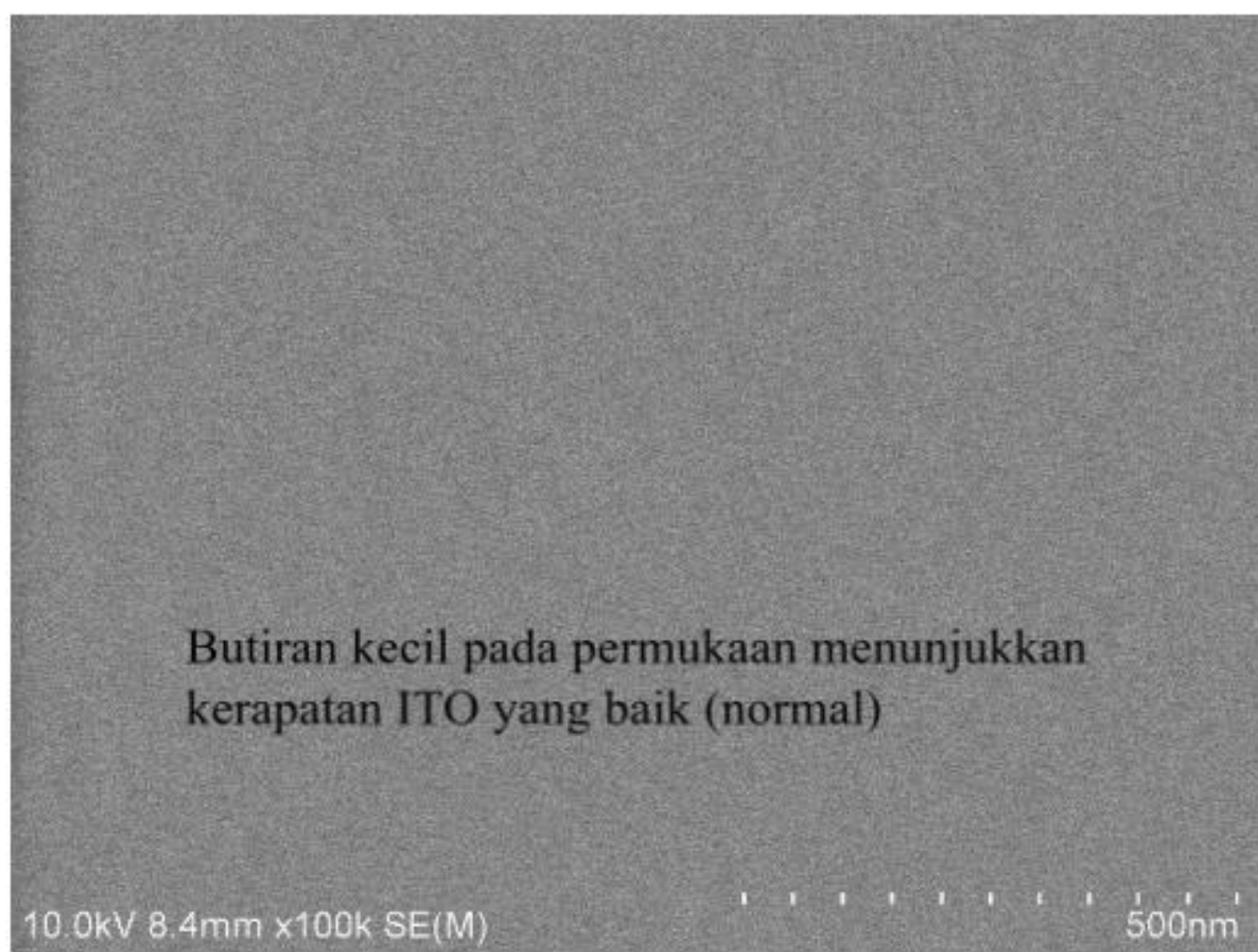

(a) Sisi atas

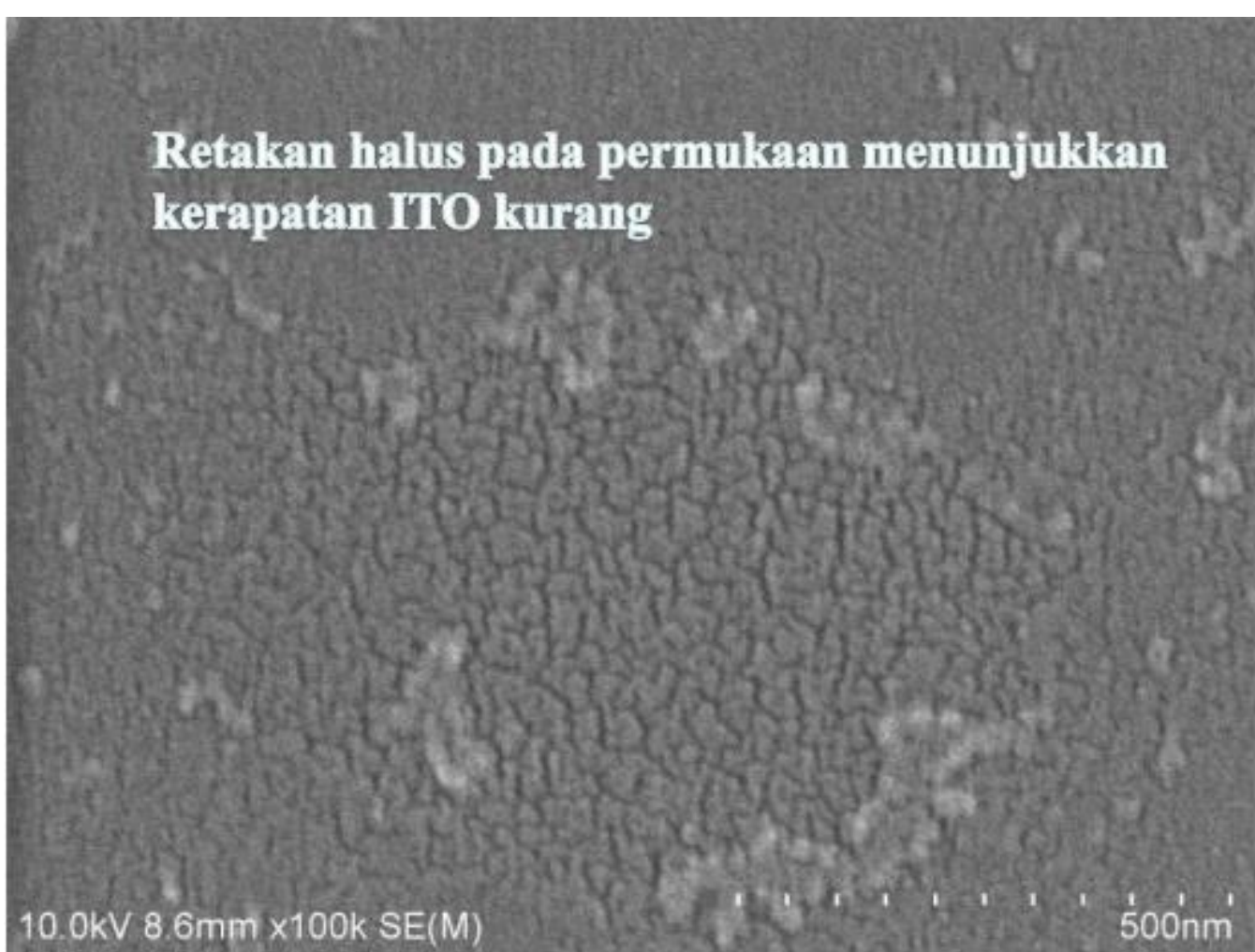

(b) Sisi bawah

Sumber: Hasil Penelitian (2020)

Gambar 10. Waktu celup dalam air 50 menit 


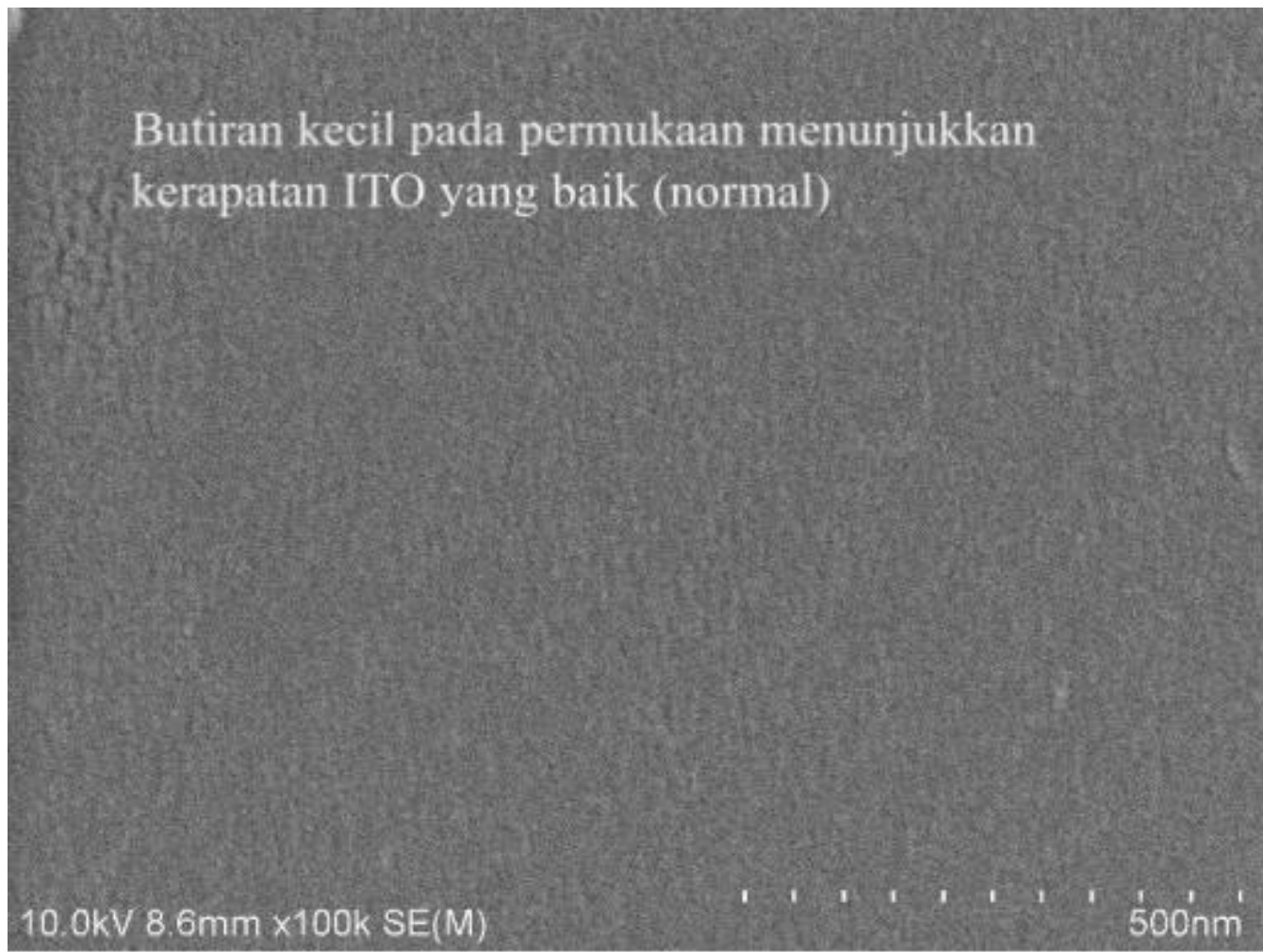

(a) Sisi atas

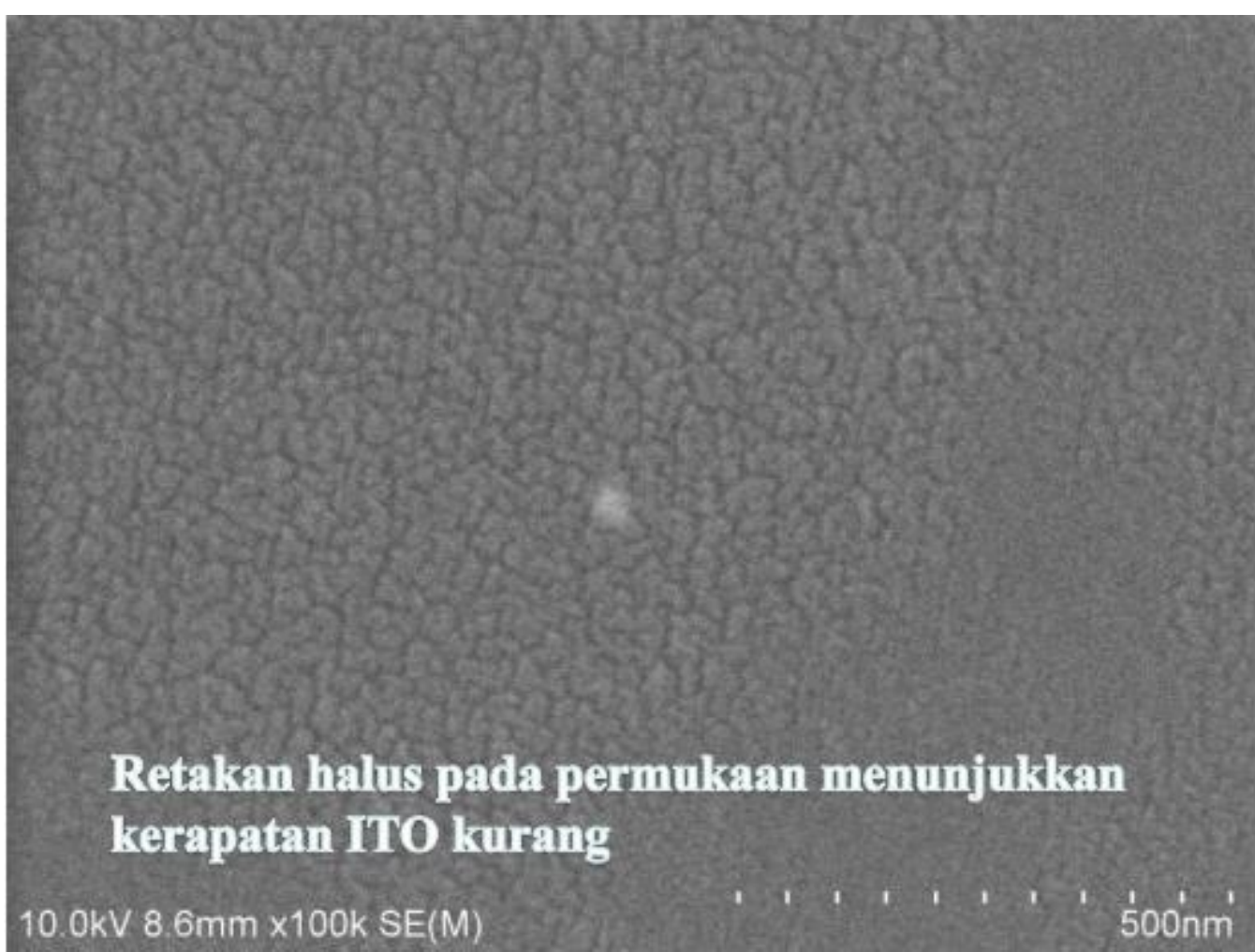

(b) Sisi bawah

Sumber: Hasil Penelitian (2020)

Gambar 11. Waktu celup dalam air 60 menit 


\section{Butiran kecil pada permukaan menunjukkan} kerapatan ITO yang baik (normal).

\section{(a) Sisi atas}

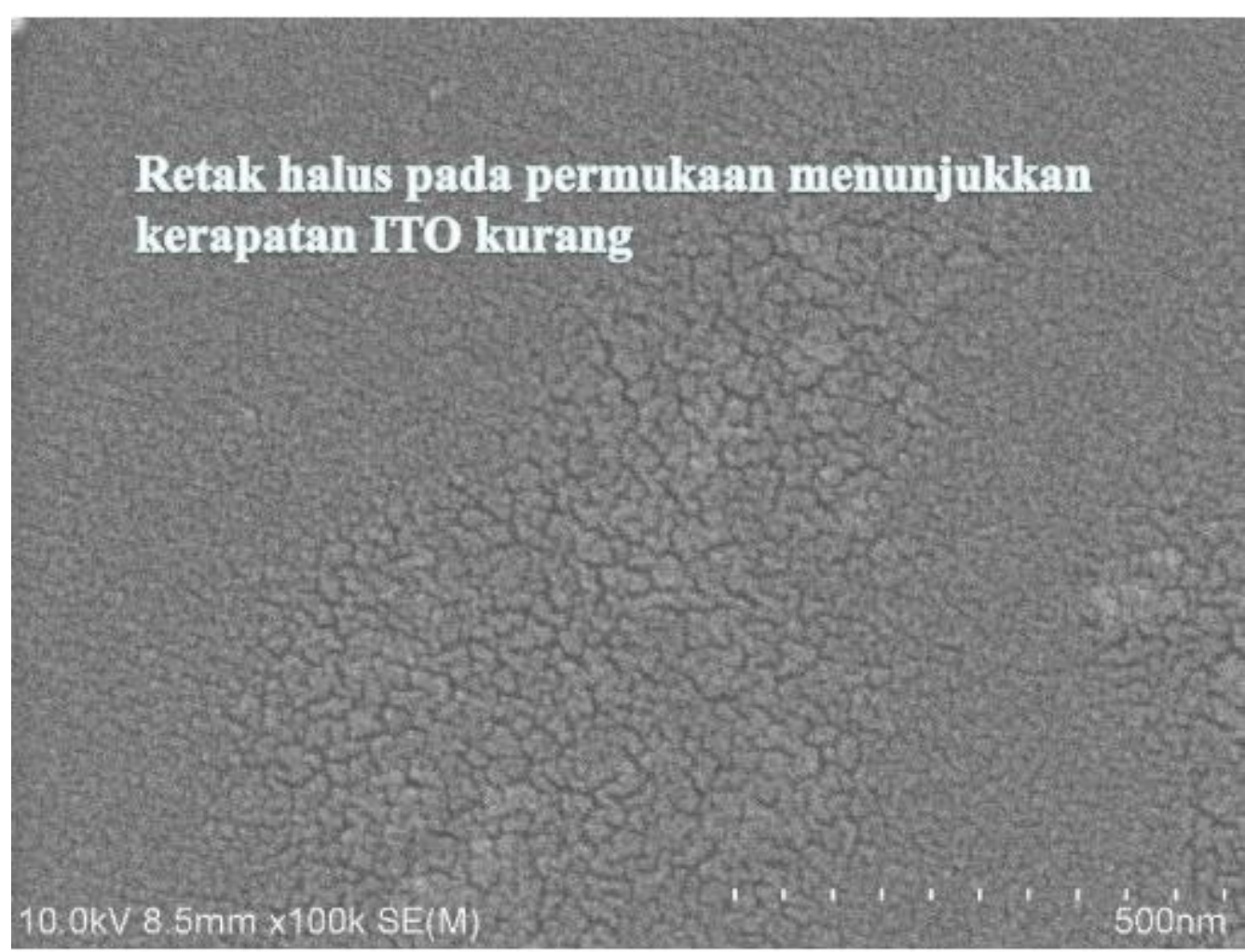

(b) Sisi bawah

Sumber: Hasil Penelitian (2020)

Gambar 12. Waktu celup dalam air 80 menit 


\section{Pembahasan}

Air bersih secara kimia bersifat netral, umumnya berfungsi sebagai pelarut atau pengencer. Bahan ITO adalah logam, sehingga tidak bereaksi secara kimia dengan air. Fungsi air pada penelitian ini adalah diasumsikan bahwa bila lapisan nanometer ketebalan lembaran ITO bermasalah (misalnya, proses sputter bermasalah, terjadi kontaminasi yang menyebabkan kerapatan berkurang pada area tertentu yang berpengaruh terhadap struktur mekanik lampisan yang terkorelasi dengan pergeseran nilai resistansi yang menyebabkan problem phase delay) maka air akan memperjelas kerusakan struktur mekanik pada permukaan ITO yang lebih memudahkan mikroskop elektron (SEM) mendeteksi secara visual kerusakan tersebut. Hipotesis yang meletakkan lapisan ITO sebagai fokus penelitian dan pemakaian air sebagai media bantu, ternyata efektif dimana puluhan sampel yang diteliti secara konsisten memperlihatkan pola "gejala" yang sama, yaitu lokasi koordinat modul touch screen yang punya problem phase delay (lokasi dideteksi oleh alat ukur terkompurisasi), menunjukkan ketidaksempurnaan proses sputtering dimana terjadi pembentukan butiran yang lebih kasar pada permukaan lapisan ITO yang menunjukkan kerapatan ITO berkurang sebagaimana diperlihatkan foto pada gambar 8,9,10,11,12.

Dari persamaan (2), nilai resistansi dipengaruhi oleh beberapa hal diluar bahan dasarnya, yaitu mobilitas dipengaruhi oleh : Impurity atoms, Vacancies, Interstitial atoms, Dislocations, Thermal vibrations of the atoms themselves.

Sedangkan resistivity $\rho$ dipengaruhi oleh : Temperature $\rightarrow$ thermal vibration, Composition $\rightarrow$ impurities, The degree of cold work of a metal specimen $\rightarrow$ plastic deformation.

Ketidakmurnian (impurity) bahan ITO akibat kontamiasi selama proses sputter (pembentukan lapisan nano meter tebal ITO pada permukaan gelas) berpengaruh signifikan terhadap nilai resistansi R. Ini terbukti dengan hasil pengamatan visual menggunakan mikroskop elektron. Hipotesis yang meletakkan resistansi pada jalur ITO sebagai penyebab problem phase delay juga diperkuat oleh efeknya terjadi setelah produk berada di tangan end user beberapa lama (produk dipakai). Dalam hal ini suhu kerja pada alat elektronik (Iphone) memperparah kerusakan strukrtur mekanik permukaan lapisan ITO dari waktu ke waktu (berkaitan dengan stress permukaan lapisan ITO sebagai respon terhadap suhu kerja), sehingga problem phase delay semakin jelas bila waktu semakin lama berada di lingkungan pemakaian /end user.

Penelusuran lebih jauh, ditemukan bahwa produk yang bermasalah hanya berasal dari fasilitas atau mesin sputter tertentu, dan pada fasilitas tersebut terdapat masalah proses vakum yang tidak disadar oleh operator. Ini merupakan bukti pendukung yang terkorelasi positif dengan temuan SEM (mikroskop elektron).

\section{Kesimpulan}

Pada penelitian kasus ini, gejala kerusakan pada modul touch screen Iphone yang dinyatakan sebagai problem "phase delay", disebabkan oleh pemekaran nilai resistansi yang terkorelasi dengan kontaminasi bahan ITO pada proses sputter. Efek arus elektrik dan suhu kerja perangkat elektronik ketika produk berada di tangan end user memberikan dampak lebih lanjut terhadap struktur mekanik lapisan nanometer ITO (jalur matriks $\mathrm{x}-\mathrm{y}$ ) yang menyebabkan nilai resistansi berubah menjadi lebih tinggi sehingga melebarkan konstanta waktu $\tau$.

\section{Referensi}

[1] Saludin. Muis, Teknologi Nano, Dalam pembuatan Sensor Layar Sentuh, Jilid 1. Jogyakarta: Grahallmu,2013.

[2] Saludin. Muis, Teknologi Nano, Dalam pembuatan Sensor Layar Sentuh, Jilid 2. Jogyakarta : Grahallmu,2013.

[3] Saludin. Muis, Teknologi Nano, Dalam pembuatan Sensor Layar Sentuh, Jilid 3. Jogyakarta : Grahallmu,2013.

[4] Saludin. Muis, Lapisan ITO dan Polimer Konduktif, Teknik Pembuatan Sensor Layar Sentuh Kapasitif. Jogyakarta : Grahallmu,2014. 
[5] Saludin. Muis, Teori Pembentukan Film (lapisan) Tipis Skala Nanometer, Karakteristik dan Contoh Aplikasi Pada Layar Sentuh. Jogyakarta : Teknosain,2016.

[6] Saludin. Muis, Teori Keandalan dan Mekanisme Korosi, Teknik Pembuatan Sensor Layar Sentuh. Jogyakarta : Grahallmu,2014.

[7] Saludin. Muis, Kontaminasi Kontrol dan Teori Difusi, Teknik Pembuatan Sensor Layar Sentuh. Jogyakarta : Grahallmu,2014.

[8] Saludin. Muis, Prinsip Dasar Penginderaan Sensor, Teori dan Aplikasi. Jogyakarta : Teknosain,2017.

[9] Saludin. Muis, Penguat Operasional (Op-Amp), Teori dan Rangkaian Dasar. Jogyakarta : Teknosain,2017.

[10] Saludin. Muis, Penguat Operasional (Op-Amp), Teori Lanjutan dan Pemakaian. Jogyakarta : Teknosain,2017 